\title{
Attempt to Determine the Cut-Off Value of Serum Ferritin for Iron Deficiency in Male College Student Runners
}

\author{
Yuki KoBAyASHI, Nami ImAi and Kazuhiro UENISHI* \\ Laboratory of Physiological Nutrition, Kagawa Nutrition University, 3-9-21 Chiyoda, \\ Sakado, Saitama 350-0288, Japan \\ (Received May 17, 2020)
}

\begin{abstract}
Summary For the evaluation of iron nutrition status, the measurement of serum ferritin levels is the most convenient and widely used technique for estimating stored iron. However, the cut-off value of serum ferritin for iron deficiency in athletes has not yet established. This study aimed to determine the cut-off value of serum ferritin to define iron deficiency in male college student runners. This study included 37-43 Japanese male college student runners for each month. Anthropometric measurements and blood collection were conducted from March to December 2018. In all months except May, significant negative correlations were observed between serum ferritin and transferrin levels, total iron binding capacity (TIBC), and unsaturated iron binding capacity. Furthermore, a significant association between serum ferritin levels and TIBC was observed by nonlinear regression analysis. The curvature radius and curvature were calculated using the data from 9 mo, and serum ferritin levels with the smallest curvature radius and the highest curvature in each month were identified. The serum ferritin levels were as follows: $35.0 \mathrm{ng} / \mathrm{mL}$ in March, $45.0 \mathrm{ng} /$ $\mathrm{mL}$ in April, $40.0 \mathrm{ng} / \mathrm{mL}$ in June, $35.0 \mathrm{ng} / \mathrm{mL}$ in July, $35.0 \mathrm{ng} / \mathrm{mL}$ in August, $35.0 \mathrm{ng} / \mathrm{mL}$ in September, $35.0 \mathrm{ng} / \mathrm{mL}$ in October, $35.0 \mathrm{ng} / \mathrm{mL}$ in November, and $40.0 \mathrm{ng} / \mathrm{mL}$ in December. The average value was $37.2 \mathrm{ng} / \mathrm{mL}$. In conclusion, the cut-off value of serum ferritin for defining iron deficiency in runners was determined to be $40.0 \mathrm{ng} / \mathrm{mL}$ in this study. This value $(40.0 \mathrm{ng} / \mathrm{mL})$ may be useful for iron deficiency screening in runners.
\end{abstract}

Key Words sports, sports nutrition, anemia, iron status, athlete

Iron is a major component of hemoglobin, which transports oxygen to the tissues of the body, and enzymes such as cytochrome, which are involved in energy metabolism; it plays a critical role in human functions $(1,2)$. Athletes who perform intense training have a high demand for iron due to iron loss via sweating, urine and excreta, hemolysis, gastrointestinal bleeding, and increased muscle mass (3-6); hence, they are at a higher risk of iron deficiency and iron deficiency anemia $(2,7)$. Progression of iron deficiency is generally divided into three stages $(8-10)$ : stage one, reduction of stored iron levels (pre-latent iron deficiency), stage two, iron-deficient erythropoiesis (latent iron deficiency), and stage three, iron deficiency anemia $(3,11)$. Continuous iron deficiency reduces the levels of stored iron, followed by decreases in serum iron levels, resulting in anemia due to a decrease in hemoglobin iron (3). Therefore, if repeated depletion in iron levels continue, there is a final progress to iron deficiency anemia. Iron deficiency anemia results in decreased performance due to reduced oxygen transport to the working muscles, decreased endurance capacity due to limited energy metabolism, and increased fatigue in athletes ( 7 , 12). Fallon reported that athletes who need a longer duration of practice showed decreased performance

\footnotetext{
*To whom correspondence should be addressed.

E-mail: uenishi@eiyo.ac.jp
}

with even mild anemia (13). However, there are no consistent conclusions as of yet about the effect of iron deficiency without anemia on performance in athletes. In a similar study among female college student rowers with iron deficiency without anemia, Della et al. stated that iron deficiency decreases the activity of iron-dependent enzymes and cytochrome required for oxygen metabolism, subsequently leading to a decline in endurance performance (14). Likewise, Hinton et al. reported that in women with iron deficiency without anemia, iron supplementation improved endurance capacity (15). However, it was reported that iron deficiency without anemia does not affect performance (16). Although the effect of iron deficiency without anemia on performance is unclear, prevention of iron deficiency in athletes is important for preventing subsequent iron deficiency anemia and for improving their performance.

For the evaluation of iron nutrition status, it is said that between the amount of iron stored in the body and serum ferritin levels correlate well $(3,17)$; further, the measurement of serum ferritin is the most convenient and widely used technique for estimating the amount of iron stored in the body (1). The WHO defines the serum ferritin cut-off values for depleted iron stores as $<15.0 \mu \mathrm{g} / \mathrm{L}$ in male and female individuals aged $5 \mathrm{y}$ or older (17). In addition, The Japanese BioIron Society defines the status of depleted stored iron using a serum ferritin level $<12.0 \mathrm{ng} / \mathrm{mL}$, whereas, iron reduction is 
defined using a serum ferritin level $<25.0 \mathrm{ng} / \mathrm{mL}$ (3). However, the cut-off of serum ferritin for iron deficiency in athletes is not yet established. Previous studies have used various cut-off values for serum ferritin to define iron deficiency in athletes: $12.0 \mathrm{ng} / \mathrm{mL}(14,18)$, $15.0 \mathrm{ng} / \mathrm{mL}$ (19), $17.0 \mathrm{ng} / \mathrm{mL}$ (20), $20.0 \mathrm{ng} / \mathrm{mL}$ (14, 21-26), $25.0 \mathrm{ng} / \mathrm{mL}(13,19,27), 30.0 \mathrm{ng} / \mathrm{mL}(2,11$, $28-33)$, $35.0 \mathrm{ng} / \mathrm{mL}(18,34)$ or $40.0 \mathrm{ng} / \mathrm{mL}$ (35). Walker et al. suggested that it is important to recognize the differences between the clinical range and optimal range for athletes (36). It is possible that the cut-off value of serum ferritin levels for the general population is lower than that in athletes. Furthermore, Rubeor et al. suggested that one of the serious limitations of studies on iron deficiency without anemia is the lack of a standard cut-off value for low serum ferritin levels (1). The difference of definition for iron deficiency may lead to differences in results between studies, hence, it is necessary to establish the cut-off of serum ferritin levels for iron deficiency in athletes.

This study aimed to determine the cut-off value of serum ferritin levels to define iron deficiency, which is important for the evaluation of iron nutrition status in athletes.

\section{MATERIALS AND METHODS}

Subjects. This study included 44 elite Japanese male college student runners (age: 19.2 $\pm 1.0 \mathrm{y}$ ). Anthropometric measurements and blood collection were conducted monthly from March to December 2018. Runners who participated the measurements in each month were analyzed. A runner who took iron preparation was excluded. The number of analyzed subjects for each month was as follows: March $(n=42)$, April $(n=43)$, May $(n=43)$, June $(n=40)$, July $(n=41)$, August $(n=37)$, September $(n=38)$, October $(n=38)$, November $(n=38)$, December $(n=37)$.

This study was designed according to the Declaration of Helsinki for experiments with human beings and was approved by the local Ethics Committee of Kagawa Nutrition University, registration number 50.

Anthropometric measurements. Body weight and body composition were measured by bioelectrical impedance analysis (InBody 720, InBody, Seoul, Korea). Height was measured with a precision of $0.1 \mathrm{~cm}$. Subjects were instructed to remove metal objects from the body and underwent measurements while being shirtless and wearing short pants. Their palms and soles were moistened with wet tissue. Body mass index (BMI) was calculated using the following formula:

BMI $\left(\mathrm{kg} / \mathrm{m}^{2}\right)=$ body weight $(\mathrm{kg}) \div[\text { height }(\mathrm{m})]^{2}$

Blood collection and analysis. Blood collection was conducted on the same day as the anthropometric measurements. All samples were collected under basal conditions after an overnight fast. Blood samples were obtained from the antecubital vein. The analysis was conducted by SRL (Tokyo, Japan). Levels of red blood cell $(\mathrm{RBC})$, hemoglobin $(\mathrm{Hb})$, hematocrit $(\mathrm{Ht})$, serum iron, serum ferritin, and transferrin were analyzed to assess iron nutrition status. Mean corpuscular volume
Table 1. Subjects' nutrient intake $(n=43)$.

Variable

\begin{tabular}{lc} 
Energy $(\mathrm{kcal} / \mathrm{d})$ & $2,648 \pm 268$ \\
Protein $(\mathrm{g} / \mathrm{d})$ & $110 \pm 20$ \\
Fat $(\mathrm{g} / \mathrm{d})$ & $68 \pm 12$ \\
Carbohydrate $(\mathrm{g} / \mathrm{d})$ & $389 \pm 41$ \\
Calcium $(\mathrm{mg} / \mathrm{d})$ & $937 \pm 358$ \\
Iron $(\mathrm{mg} / \mathrm{d})$ & $12.7[9.8-14.1]$ \\
\hline
\end{tabular}

Data are expressed as mean \pm standard deviation or median [25-75th percentile].

(MCV), mean corpuscular hemoglobin (MCH), and mean corpuscular hemoglobin concentration (MCHC) were calculated by $\mathrm{RBC}, \mathrm{Hb}$, and $\mathrm{Ht}$. Total iron binding capacity (TIBC), unsaturated iron binding capacity (UIBC), and transferrin saturation were calculated using the following formulas:

TIBC $(\mu \mathrm{g} / \mathrm{dL})=$ transferrin $(\mathrm{mg} / \mathrm{dL}) \times 1.3$

$\operatorname{UIBC}(\mu \mathrm{g} / \mathrm{dL})=$ TIBC $(\mu \mathrm{g} / \mathrm{dL})-$ serum iron $(\mu \mathrm{g} / \mathrm{dL})$

Transferrin saturation $(\%)$

$=\operatorname{serum}$ iron $(\mu \mathrm{g} / \mathrm{dL}) \div \mathrm{TIBC}(\mu \mathrm{g} / \mathrm{dL}) \times 100$

Survey of nutrient intake. A survey of food intake was conducted using food frequency questionnaire in March (37). Forty-three runners completed the survey. A runner took iron preparation, and six runners took iron supplement.

In addition, we continue to nutritional support this team, and provide meals several times a year.

Statistical analysis. Statistical analyses were performed using the SPSS Statistics Version 20 (IBM Japan, Tokyo, Japan). Significance was indicated using a $p$ value $<0.05$.

Normality of the distributions was verified using the Shapiro-Wilk test. Data were expressed as mean \pm standard deviation for variables with normal distribution or median [25-75th percentile] for variables with nonnormal distribution.

The correlations between serum ferritin and other iron-related indices were examined using Spearman's rank correlation coefficient to estimate the association between each variable. The association between serum ferritin levels and TIBC was assessed by nonlinear regression analysis of the reciprocal function model. The examination method used by Tsugawa et al. for dietary vitamin $\mathrm{K}$ requirement was used as a reference (38), to determine the cut-off value for serum ferritin levels using curvature. Curvature is a parameter that shows the degree of a curve and is the reciprocal of the radius of the circle that is tangent to the curve. The circle that is tangent to the sharper curve is smaller and hence, has a higher curvature with a smaller curvature radius (38). In each month, the curvature radius and curvature were calculated based on regression equation with serum ferritin levels of 20.0, 25.0, 30.0, 35.0, $40.0,45.0$, or $50.0 \mathrm{ng} / \mathrm{mL}$; serum ferritin levels with the smallest curvature radius and highest curvature were identified and evaluated as a cut-off value for iron 
Table 2. Subjects' characteristics for each month.

\begin{tabular}{lccrrr}
\hline \multicolumn{1}{c}{ Variable } & March $(n=42)$ & April $(n=43)$ & May $(n=43)$ & June $(n=40)$ & July $(n=41)$ \\
\hline Height $(\mathrm{cm})$ & $172.5 \pm 4.4$ & $172.6 \pm 4.5$ & $172.7 \pm 4.5$ & $172.5 \pm 4.3$ & $172.3 \pm 4.3$ \\
Body weight $(\mathrm{kg})$ & $57.3[55.0-61.4]$ & $57.6 \pm 4.7$ & $57.4 \pm 4.5$ & $57.1 \pm 4.0$ & $57.5 \pm 3.9$ \\
BMI $\left(\mathrm{kg} / \mathrm{m}^{2}\right)$ & $19.5 \pm 1.1$ & $19.3 \pm 1.1$ & $19.2 \pm 1.0$ & $19.2 \pm 1.0$ & $19.3 \pm 1.0$ \\
Body fat $(\%)$ & $10.2 \pm 2.3$ & $10.0 \pm 2.3$ & $9.3 \pm 2.1$ & $9.6 \pm 2.3$ & $8.9[7.5-10.0]$ \\
Lean body mass (kg) & $52.1 \pm 4.3$ & $51.8 \pm 4.4$ & $52.1 \pm 4.2$ & $51.6 \pm 4.0$ & $52.2 \pm 4.0$ \\
Skeletal muscle mass (kg) & $29.5 \pm 2.6$ & $29.3 \pm 2.6$ & $29.4 \pm 2.5$ & $29.2 \pm 2.5$ & $29.5 \pm 2.4$ \\
\hline RBC $\left(\times 10^{4} / \mu \mathrm{L}\right)$ & $508 \pm 22$ & $498 \pm 30$ & $490 \pm 26$ & $495 \pm 28$ & $469 \pm 32$ \\
Hb $(\mathrm{g} / \mathrm{dL})$ & $15.3 \pm 0.7$ & $15.2 \pm 1.0$ & $14.8 \pm 0.7$ & $15.1 \pm 0.8$ & $14.4 \pm 0.9$ \\
Ht $(\%)$ & $46.7 \pm 1.8$ & $46.3 \pm 2.3$ & $45.8 \pm 1.9$ & $46.0 \pm 2.0$ & $43.2 \pm 2.4$ \\
MCV (fL) & $91.9 \pm 2.5$ & $93.1 \pm 2.5$ & $93.6 \pm 2.5$ & $93.0 \pm 2.5$ & $92.1 \pm 2.7$ \\
MCH $(\mathrm{pg})$ & $30.1 \pm 1.0$ & $30.4[29.9-31.3]$ & $30.3 \pm 0.9$ & $30.6 \pm 0.8$ & $30.6 \pm 0.8$ \\
MCHC $(\%)$ & $32.7 \pm 0.7$ & $32.8 \pm 0.9$ & $32.4 \pm 0.7$ & $32.9 \pm 0.6$ & $33.3 \pm 0.6$ \\
Serum ferritin (ng/mL) & $45.0[29.5-59.3]$ & $46.5[34.8-64.5]$ & $51.4[35.0-61.3]$ & $46.0[30.9-58.8]$ & $42.7[25.6-56.0]$ \\
Transferrin $(\mathrm{mg} / \mathrm{dL})$ & $269 \pm 31$ & $266 \pm 29$ & $267 \pm 30$ & $259 \pm 31$ & $254 \pm 30$ \\
Serum iron $(\mu \mathrm{g} / \mathrm{dL})$ & $126[102-150]$ & $96[76-138]$ & $111 \pm 34$ & $69[55-95]$ & $96 \pm 31$ \\
TIBC $(\mu \mathrm{g} / \mathrm{dL})$ & $349 \pm 41$ & $346 \pm 38$ & $347 \pm 39$ & $337 \pm 41$ & $331 \pm 39$ \\
UIBC $(\mu \mathrm{g} / \mathrm{dL})$ & $223[178-258]$ & $240 \pm 48$ & $236 \pm 54$ & $259 \pm 44$ & $234 \pm 53$ \\
Transferrin saturation $(\%)$ & $36.4[27.9-45.3]$ & $30.5 \pm 11.6$ & $32.4 \pm 10.7$ & $20.3[16.3-24.4]$ & $27.3[21.4-36.5]$ \\
\hline
\end{tabular}

\begin{tabular}{|c|c|c|c|c|c|}
\hline Variable & August ( $n=37)$ & September $(n=38)$ & October $(n=38)$ & November $(n=38)$ & December $(n=37)$ \\
\hline Height $(\mathrm{cm})$ & $172.8 \pm 4.4$ & $172.4 \pm 4.5$ & $172.5 \pm 4.5$ & $172.4 \pm 4.5$ & $172.3 \pm 4.5$ \\
\hline Body weight (kg) & $57.6 \pm 4.1$ & $57.3 \pm 4.0$ & $57.8 \pm 4.0$ & $57.6 \pm 3.8$ & $57.7 \pm 3.8$ \\
\hline BMI $\left(\mathrm{kg} / \mathrm{m}^{2}\right)$ & $19.3 \pm 1.0$ & $19.3 \pm 1.0$ & $19.4 \pm 1.0$ & $19.4 \pm 1.0$ & $19.5 \pm 0.9$ \\
\hline Body fat $(\%)$ & $9.2 \pm 2.1$ & $9.9 \pm 2.3$ & $10.4 \pm 2.2$ & $9.7 \pm 2.1$ & $10.5 \pm 2.3$ \\
\hline Lean body mass (kg) & $52.3 \pm 4.0$ & $51.7 \pm 3.9$ & $51.8 \pm 3.9$ & $52.0 \pm 3.6$ & $51.7 \pm 3.6$ \\
\hline Skeletal muscle mass $(\mathrm{kg})$ & $29.6 \pm 2.4$ & $29.3 \pm 2.3$ & $29.3 \pm 2.3$ & $29.4 \pm 2.2$ & $29.2 \pm 2.1$ \\
\hline $\mathrm{RBC}\left(\times 10^{4} / \mu \mathrm{L}\right)$ & $500 \pm 30$ & $484 \pm 27$ & $497 \pm 28$ & $485 \pm 28$ & $495 \pm 28$ \\
\hline $\mathrm{Hb}(\mathrm{g} / \mathrm{dL})$ & $15.4 \pm 0.9$ & $15.0 \pm 0.8$ & $15.3 \pm 0.8$ & $14.8 \pm 0.8$ & $15.3 \pm 0.8$ \\
\hline $\mathrm{Ht}(\%)$ & $46.9 \pm 2.1$ & $45.5 \pm 2.2$ & $45.6 \pm 2.2$ & $44.8 \pm 2.0$ & $45.6 \pm 2.1$ \\
\hline MCV (fL) & 94.3 [93.0-95.2] & $93.9 \pm 2.4$ & $91.8 \pm 1.9$ & $92.5 \pm 1.9$ & $92.1 \pm 1.8$ \\
\hline $\mathrm{MCH}(\mathrm{pg})$ & $30.8 \pm 0.8$ & $31.0 \pm 0.7$ & $30.8 \pm 0.9$ & $30.5 \pm 0.8$ & $30.8 \pm 0.8$ \\
\hline $\mathrm{MCHC}(\%)$ & $32.8 \pm 0.8$ & $33.0 \pm 0.6$ & $33.6 \pm 0.6$ & $33.0 \pm 0.6$ & $33.5 \pm 0.6$ \\
\hline Serum ferritin (ng/mL) & 43.7 [27.9-53.5] & $43.1[22.7-58.8]$ & $39.9[30.9-56.1]$ & $48.8[32.6-59.5]$ & $38.9[29.1-57.1]$ \\
\hline Transferrin (mg/dL) & $267 \pm 29$ & $264 \pm 32$ & $266 \pm 29$ & $262 \pm 31$ & $273 \pm 28$ \\
\hline Serum iron $(\mu \mathrm{g} / \mathrm{dL})$ & $107 \pm 45$ & $116 \pm 31$ & 164 [132-189] & $79[58-105]$ & 76 [60-97] \\
\hline $\mathrm{TIBC}(\mu \mathrm{g} / \mathrm{dL})$ & $347 \pm 38$ & $344 \pm 41$ & $345 \pm 38$ & $341 \pm 41$ & $355 \pm 37$ \\
\hline $\mathrm{UIBC}(\mu \mathrm{g} / \mathrm{dL})$ & $239 \pm 65$ & $227 \pm 48$ & $183 \pm 59$ & $257 \pm 48$ & $271 \pm 42$ \\
\hline Transferrin saturation (\%) & $31.7 \pm 14.0$ & $34.1 \pm 9.3$ & $47.8 \pm 13.3$ & $24.6 \pm 9.6$ & $22.3[16.7-27.3]$ \\
\hline
\end{tabular}

Data are expressed as mean \pm standard deviation or median [25-75th percentile].

deficiency. The cut-off value indicates the point at which the TIBC increases sharply with decreasing serum ferritin levels.

\section{RESULTS}

Tables 1 and 2 show the subjects' nutrient intake and characteristics for each month. The average BMI in each month ranged from 19.2 to $19.5 \mathrm{~kg} / \mathrm{m}^{2}$. The median serum ferritin levels in each month ranged from 38.9 to $51.4 \mathrm{ng} / \mathrm{mL}$.

The correlations between serum ferritin levels and other iron-related indices are shown in Table 3. In all months except May, serum ferritin levels showed signifi- cant negative correlations with transferrin levels, TIBC, and UIBC.

We performed nonlinear regression analysis to assess the association between serum ferritin levels and TIBC. Figure 1 shows the analyzed nonlinear regression curve. A significant association between serum ferritin levels and TIBC was observed in all months except May. Therefore, the curvature radius and curvature were calculated using 9 mo data (except those for May) (Table 4). Serum ferritin levels with the smallest curvature radius and highest curvature in each month were as follows: $35.0 \mathrm{ng} / \mathrm{mL}$ (March), $45.0 \mathrm{ng} / \mathrm{mL}$ (April), $40.0 \mathrm{ng} / \mathrm{mL}$ (June), $35.0 \mathrm{ng} / \mathrm{mL}$ (July), $35.0 \mathrm{ng} / \mathrm{mL}$ 


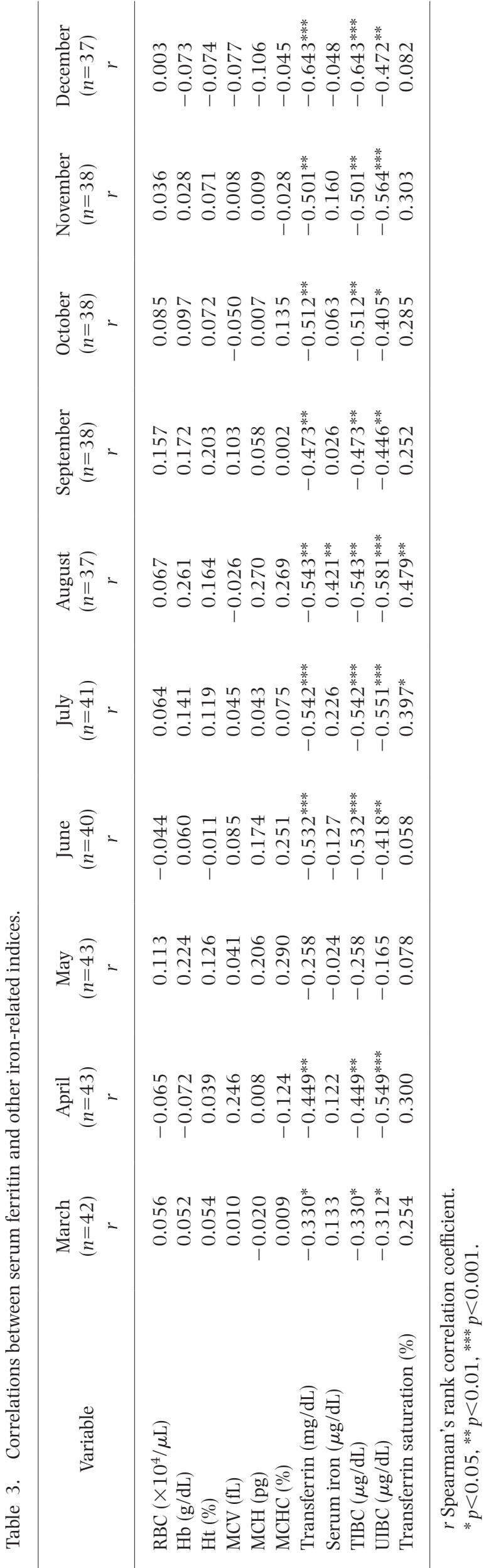

(August), $35.0 \mathrm{ng} / \mathrm{mL}$ (September), $35.0 \mathrm{ng} / \mathrm{mL}$ (October), $35.0 \mathrm{ng} / \mathrm{mL}$ (November), and $40.0 \mathrm{ng} / \mathrm{mL}$ (December). The average level was $37.2 \mathrm{ng} / \mathrm{mL}$.

\section{DISCUSSION}

This study was conducted to determine the cut-off value for serum ferritin to define iron deficiency in male college student runners.

Ten blood samples were used to determine the cut-off value of serum ferritin for iron deficiency. The WHO thresholds for iron deficiency have been defined by examining the highest concentration found in patients with iron deficiency anemia. These patients are classified as microcytic, having either an absence of stainable iron in their bone marrow or showing a response to therapeutic iron (17). In addition, The Japanese BioIron Society, has defined the cut-off value for serum ferritin levels based on liver iron stores (3). Bone marrow iron staining has been regarded as the reference for evaluating other iron tests (10). Liver biopsy can accurately assess iron nutrition status; however, it is invasive compared to blood collection. Absence of stainable iron in the bone marrow may indicate that levels of iron in the body is already depleted. Furthermore, some studies have defined the cut-off value for serum ferritin with regard to performance $(1,13,15,19)$. Rubeor et al. suggested a cut-off value of serum ferritin for supplementation (1). They showed that there was no significant improvement in performance after iron supplementation when the cut-off value was higher than $20.0 \mathrm{ng} / \mathrm{mL}$. On the contrary, six of eight studies showed that a serum ferritin cut-off value of $20.0 \mathrm{ng} /$ $\mathrm{mL}$ or less could be used to demonstrate significant improvements in performance and suggested that iron supplementation may play a role in improving performance in athletes with a serum ferritin levels of $20.0 \mathrm{ng} / \mathrm{mL}$ or less (1).

This study investigated the cut-off value of serum ferritin for screening, prevention, and early detection of pre-latent iron deficiency, stage one of progression of iron deficiency. When stored iron is depleted, serum ferritin synthesis decreases and transferrin increase in the liver, followed by an increase in the TIBC (3). Hence, this mechanism may be responsible for the significant negative correlations observed in this study. Since the daily variation in TIBC is considered to be relatively small and since it does not change until stored iron starts getting depleted, evaluating this indicator may reduce the likelihood of false detection of iron deficiency $(12,39)$. In addition, The Japanese BioIron Society uses TIBC in the diagnostic criteria for iron deficiency (3). Because TIBC does not change until stored iron begins to reduce, it was assumed that the amount of body stored iron starts to decrease at the point when TIBC begins to increase. Therefore, in this study, we represented the relationship between serum ferritin and TIBC as a curve, and used curvature to identify serum ferritin levels when the TIBC began to increase rapidly. The point at the highest curvature and smallest curvature radius was considered as the cut-off value of serum ferritin level for iron 


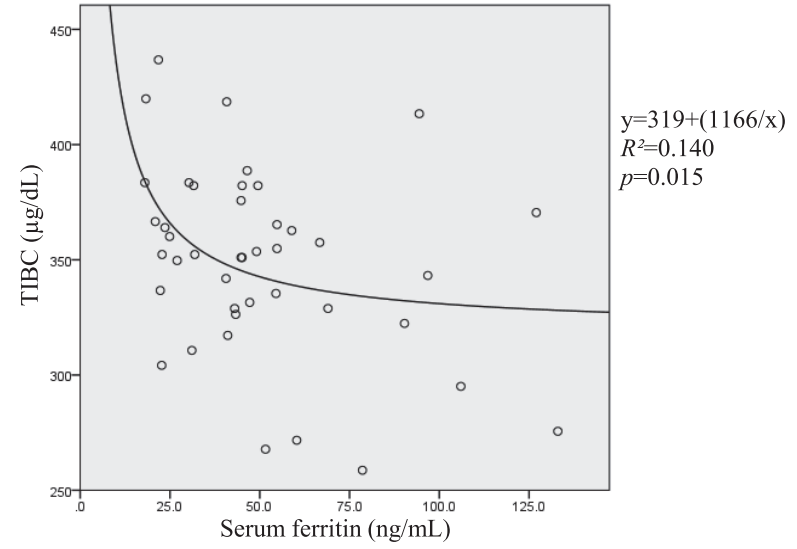

(A) March (n=42)
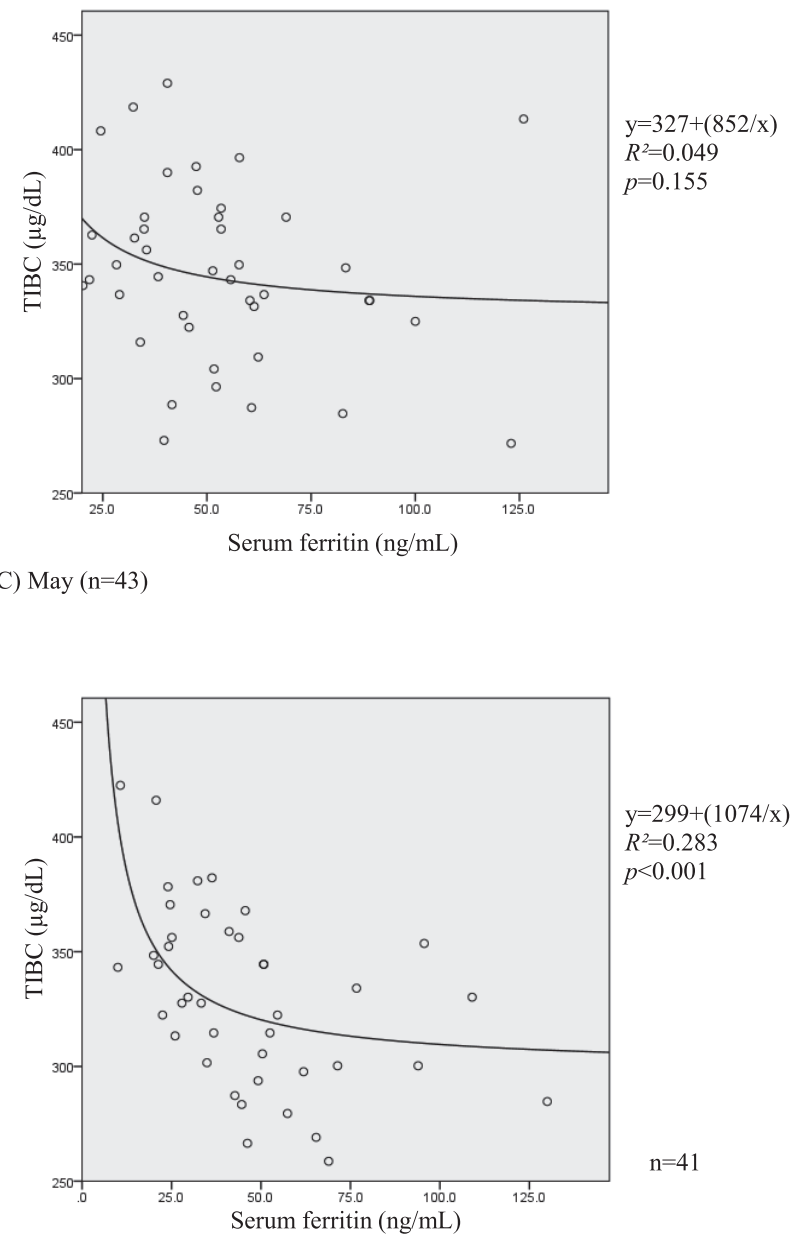

(E) July (n=41)
(C) May $(n=43)$

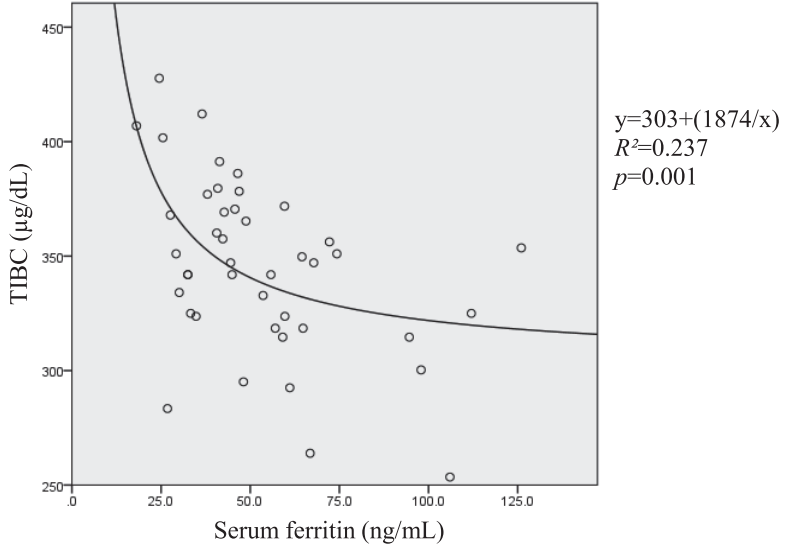

(B) April $(\mathrm{n}=43)$

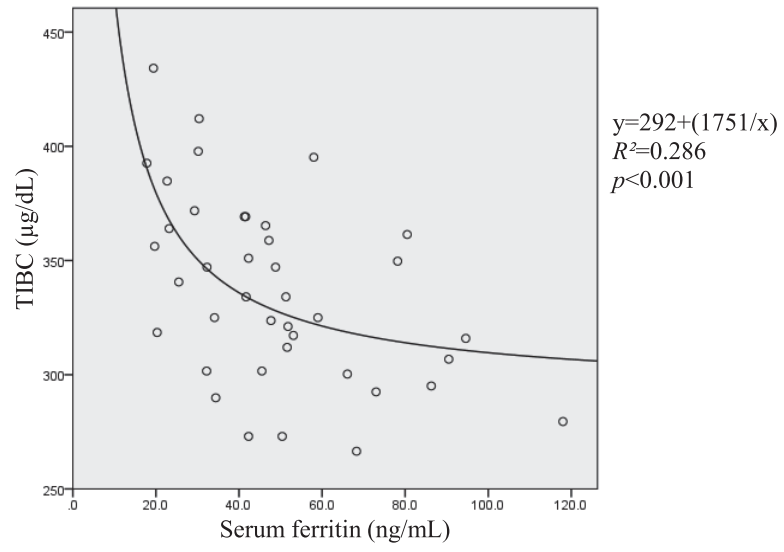

(D) June ( $\mathrm{n}=40$ )

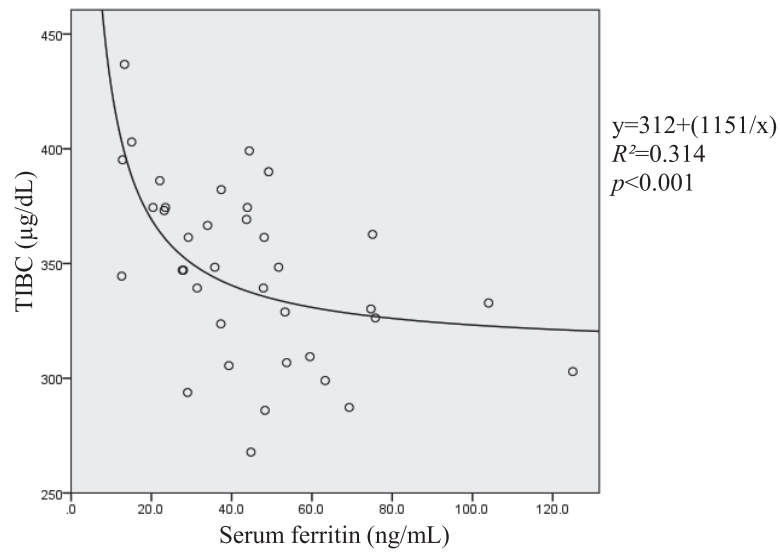

(F) August (n=37)

Fig. 1.

deficiency. The average of nine serum ferritin levels when curvature was the highest was $37.2 \mathrm{ng} / \mathrm{mL}$ in this study. It is suggested that iron supplementation increases endurance capacity in women with iron deficiency without anemia $(<16.0 \mathrm{ng} / \mathrm{mL}$ of serum ferritin) (15). Multiple regression analysis was carried out in female college student rowers and showed that serum ferritin levels, height, and years of rowing experience were significant predictors of $2-\mathrm{km}$ performance time
(14). Thus, a significant association was seen between performance time and the classification of serum ferritin $(15.0 \mathrm{ng} / \mathrm{mL}$ or $25.0 \mathrm{ng} / \mathrm{mL})$. However, no association was observed in the classification of serum ferritin $(30.0 \mathrm{ng} / \mathrm{mL})$. Fallon suggested that from the point of view of performance, serum ferritin levels in athletes should remain 16.0 or $20.0 \mathrm{ng} / \mathrm{mL}$ at least (13). A previous report suggested that the cut-off value for serum ferritin is still debatable, and the cut-off may be slightly 


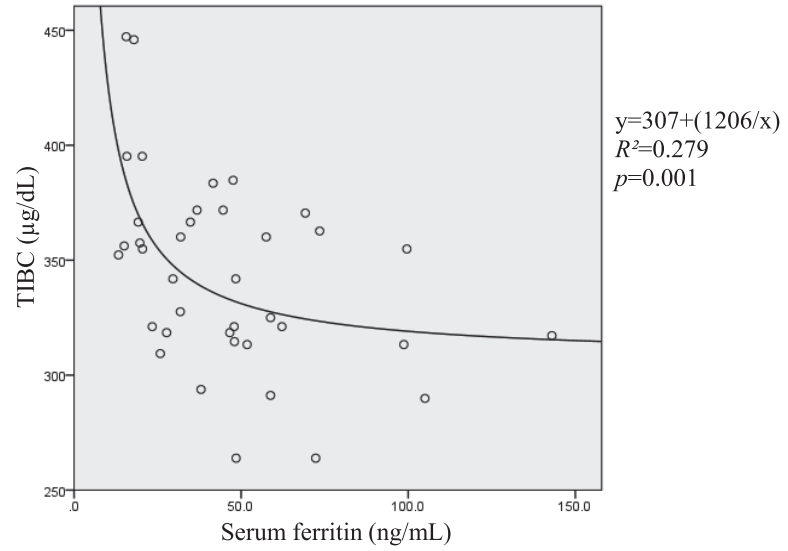

(G) September $(\mathrm{n}=38)$

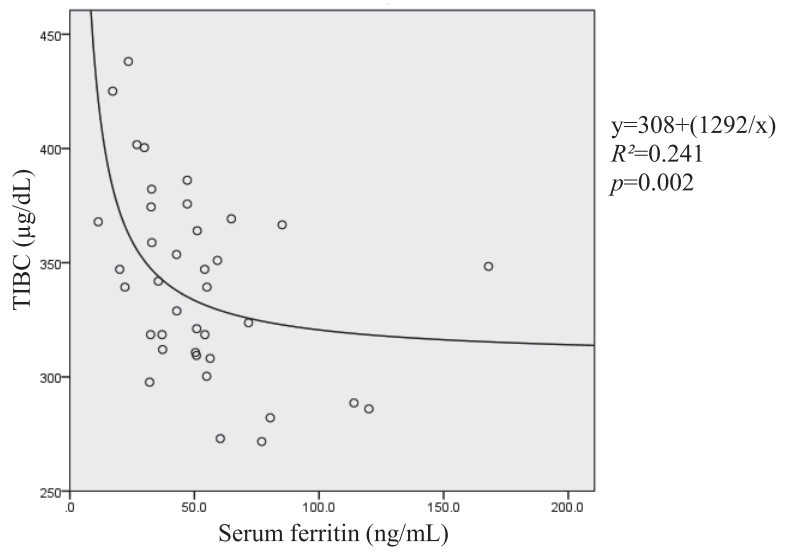

(I) November $(\mathrm{n}=38)$

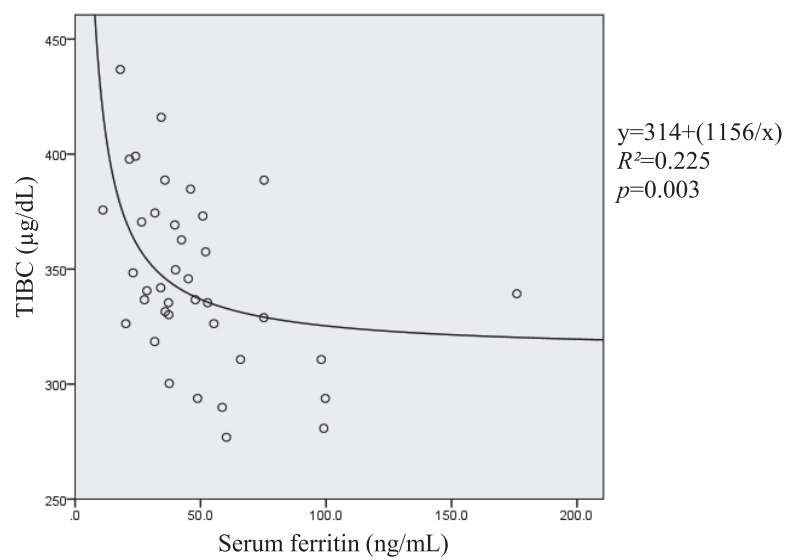

(H) October $(\mathrm{n}=38)$

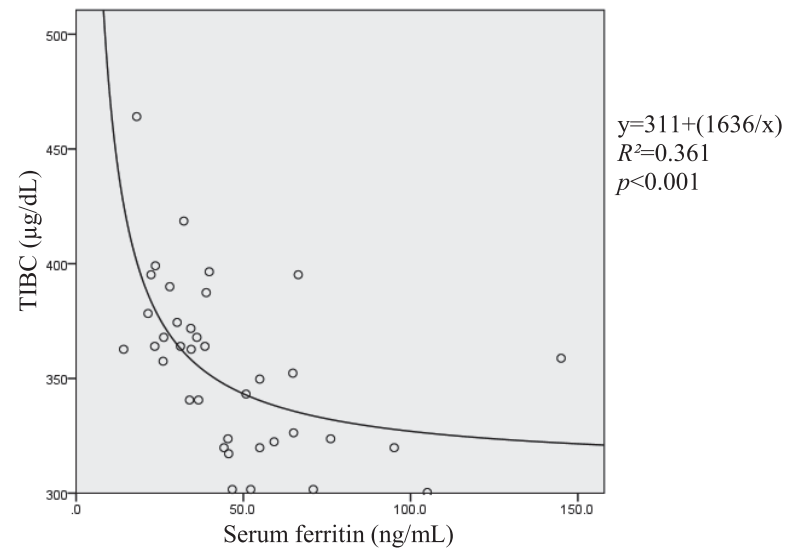

(J) December $(\mathrm{n}=37)$

Fig. 1. Association between serum ferritin and TIBC. Nonlinear regression analysis of reciprocal function model.

higher considering not only erythropoiesis but also clinical symptoms of iron deficiency, such as fatigue (2). The study also suggested that the cut-off value of $30.0 \mathrm{ng} / \mathrm{mL}$ for serum ferritin in athletes seems to be the most plausible (2). Moreover, Woods et al. reported that intravenous iron injections for $4 \mathrm{wk}$ did not show significant improvement in hemoglobin mass or performance; however, decreased fatigue and mood disorders were observed (28). Serum ferritin levels less than $20.0 \mathrm{ng} / \mathrm{mL}$ or $25.0 \mathrm{ng} / \mathrm{mL}$ may affect performance in athletes as suggested in previous studies. Furthermore, it was stated that the cut-off value of serum ferritin should be set higher than $12.0 \mathrm{ng} / \mathrm{mL}$ considering the intra-individual variation in serum ferritin levels if the purpose is early detection of iron deficiency in female college students $(8)$. Thus, it is necessary for the cut-off value to be higher in athletes than the serum ferritin level considering the effects on performance. Accordingly, it was determined that the cut-off value of serum ferritin in runners is $40.0 \mathrm{ng} / \mathrm{mL}$, and this cut-off may help in the prevention and early detection of iron deficiency in runners.

Meanwhile, serum ferritin levels falsely increase with inflammation $(14,39)$. It is said that iron deficiency is not ruled out even if serum ferritin levels are in the nor- mal range (3). Although serum ferritin is the most useful index for screening and evaluating the iron nutrition status, the index may not reflect iron nutrition status according to inflammation. Lee et al. stated that the accurate evaluation of the presence and severity of iron deficiency requires the combined evaluation of transferrin, transferrin saturation, TIBC, serum ferritin, and $\mathrm{Hb}$ (12). Subsequently, for evaluating iron nutrition status, we need to assess a combination of indicators, and it may also be necessary to assess inflammatory status.

This study has some limitations. The sex and sports disciplines of subjects who participated in this study were restricted. The cut-off values for serum ferritin suggested by the WHO and The Japan BioIron Society are the same for both male and female individuals; however, there are previous studies that have used different cut-offs for the sexes. It is also necessary the consideration of cut-off using same method in large population not restricted gender and sports disciplines in the future. Furthermore, this study did not consider inflammation. Intense exercise may induce a significant increase in the levels of pro-inflammatory and inflammatory responsive cytokines (40). Athletes often show inflammation due to routine intense training; hence, subjects with high serum ferritin levels due to inflammation might 


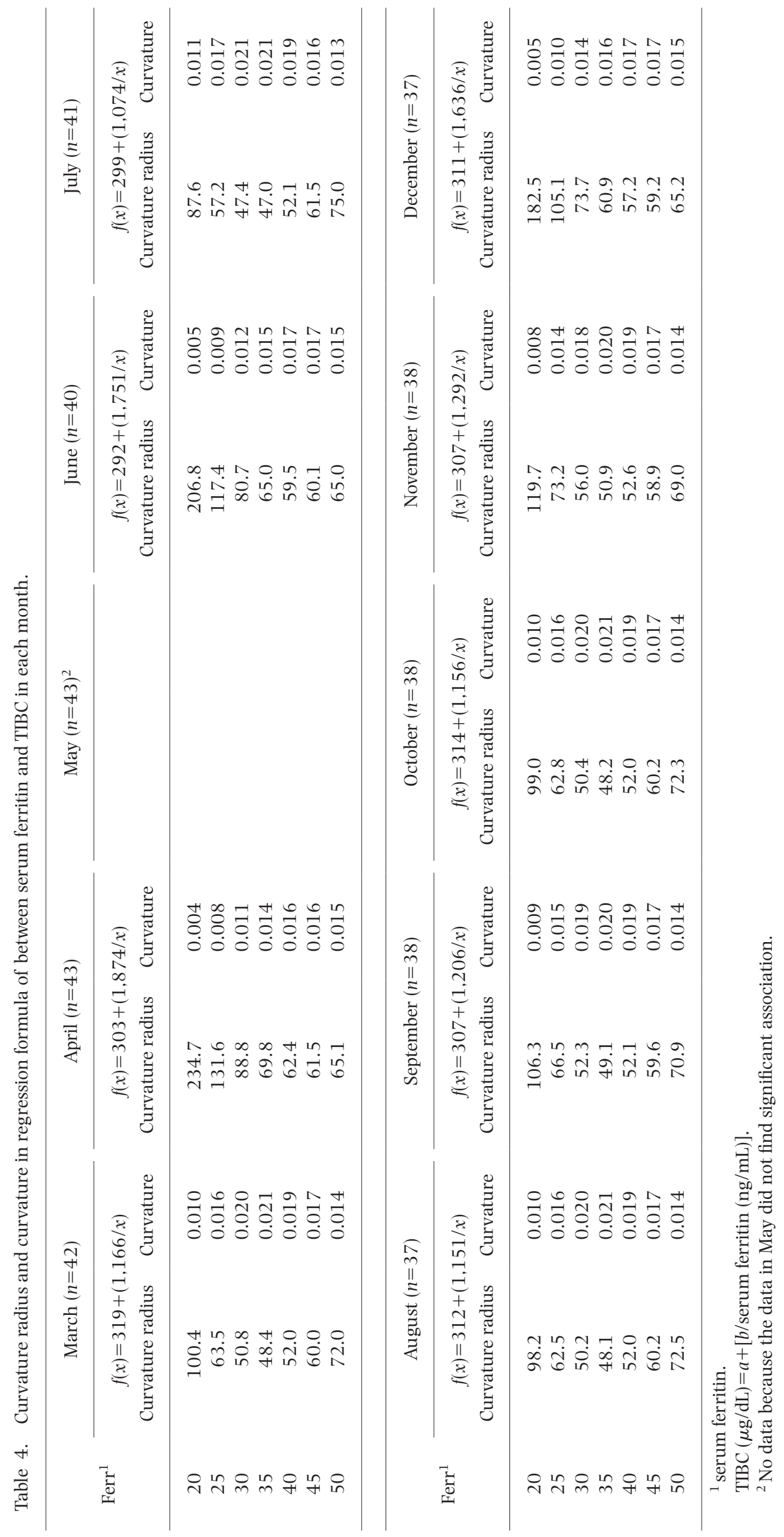


have been included in this study.

Despite the limitations, to our knowledge, this is the first study to evaluate the cut-off value of serum ferritin using curvature. Moreover, it was stated that considering iron metabolism in athletes, a single measurement limit diagnostic value (41); however, this study used long-term data for $1 \mathrm{y}$ and considered the variability in serum ferritin levels.

\section{CONCLUSIONS}

The cut-off value of serum ferritin for iron deficiency in runners was determined to be $40.0 \mathrm{ng} / \mathrm{mL}$. This cutoff value $(40.0 \mathrm{ng} / \mathrm{mL})$ may be useful for screening of iron deficiency in runners. For prevention of iron deficiency, it is important to establish a cut-off value for serum ferritin in athletes; this is also essential for future studies regarding iron metabolism in athletes.

\section{Authorship}

Research conception and design: YK, NI, and KU; experiments: YK, NI, and KU; statistical analysis of the data: YK, NI, and KU; interpretation of the data: YK, NI, and KU; writing of the manuscript: YK, NI, and KU.

\section{Disclosure of state of COI}

No conflicts of interest to be declared.

\section{Acknowledgments}

We would like to thank all participants and the staff members.

\section{REFERENCES}

1) Rubeor A, Goojha C, Manning J, White J. 2018. Does iron supplementation improve performance in iron-deficient nonanemic athletes? Sports Health 10: 400-405.

2) Clénin G, Cordes M, Huber A, Schemacher YO, Noack P, Scales J, Kniemler S. 2015. Iron deficiency in sportsdefinition, influence on performance and therapy. Swiss Med Wkly 145: 14196-14210.

3) The Japanese BioIron Society. 2015. Guidelines for Treating Anemia by Proper Use of Iron Preparations. Kyobunsya, Hokkaido (in Japanese).

4) Kazami K, Ashida K, Sato Y, Arai T, Kazami M, Ohsaki S, Kobayashi S. 2014. Nutrition interventions improve anemic status in male college long-distance runners. Jpn J Phys Fitness Sports Med 63: 313-321 (in Japanese).

5) Dang CV. 2001. Runner's anemia. JAMA 286: 714716.

6) Horii A. 1990. Effect of physical training on red blood cell properties and on the amount of total hemoglobin. J Med Soc Toho 36: 333-347 (in Japanese).

7) Owen AL, Cossio-Bolaños MA, Dunlop G, Rouissi M, Chtara M, Braqazzi NL, Chamari K. 2018. Stability in post-seasonal hematological profiles in response to high-competitive match-play loads within elite top-level European soccer players: implications from a pilot study. J Sports Med 10: 157-166.

8) Kamei A, Ishida H, Uenishi K, Suzuki H. 2003. Relationship between iron nutritional status assessed on repeatedly sampled blood specimens and long-term dietary iron intake-Young adult women's case- - Jpn J
Nutr Diet 61: 99-108 (in Japanese).

9) Gropper SS, Blessing D, Dunham K, Barksdale JM. 2006. Iron status of female collegiate athletes involved in different sports. Biol Trace Elem Res 109: 1-14.

10) World Health Organization (WHO). 2007. Assessing the iron status of populations: including literature reviews: report of a Joint World Health Organization/Centers for Disease Control and Prevention Technical Consultation on the Assessment of Iron Status at the Population Level. Geneva, Switzerland.

11) Malczewska-Lenczowska J, Orysiak J, Szczepañska B, Turowski D, Burkhard-Jaqoziñska K, Gajewski J. 2017. Reticulocyte and erythrocyte hypochromia markers in detection of iron deficiency in adolescent female athletes. Biol Sport 34: 111-118.

12) Lee EC, Fragala MS, Kavouras SA, Queen RM, Pryor JL, Casa DJ. 2017. Biomarkers in sports and exercise: Tracking health, performance, and recovery in athletes. J Strength Cond Res 10: 2920-2937.

13) Fallon KE. 2004. Utility of hematological and iron-related screening in elite athletes. Clin J Sport Med 14: 145-152.

14) Della Valle DM, Haas JD. 2011. Impact of iron depletion without anemia on performance in trained endurance athletes at the beginning of a training season: A study of female collegiate rowers. Int J Sport Nutr Exerc Metab 21: 501-506.

15) Hinton PS, Giordano C, Brownlie T, Haas JD. 2000. Iron supplementation improves endurance after training in iron-depleted, nonanemic women. J Appl Physiol 88: 1103-1111.

16) Newhouse IJ, Clement DB, Taunton JE, McKenzie DC. 1989. The effects of prelatent/latent iron deficiency on physical work capacity. Med Sci Sports Exerc 21: 263268.

17) World Health Organization (WHO). 2001. Iron Deficiency Anaemia Assessment, Prevention, and Control: A guide for programme managers. Geneva, Switzerland.

18) Koehler K, Braun H, Achtzehn S, Hildebrand U, Predel HG, Mester J, Schänzer W. 2012. Iron status in elite young athletes: gender-dependent influences of diet and exercise. Eur J Appl Physiol 112: 513-523.

19) Coates A, Mountjoy M, Burr J. 2017. Incidence of iron deficiency and iron deficient anemia in elite runners and traiathletes. Clin J Sport Med 27: 493-498.

20) Masuda R, Imamura H, Yamashita A, Miyahara K, Noda Y, Hamada S. 2008. Nutrient intake and iron status of female collegiate lacrosse players. Jpn J Nutr Diet 66: 305-310 (in Japanese).

21) Pizza FX, Flynn MG, Boone JB, Rodriquez-Zayas JR, Andres FF. 1997. Serum haptoglobin and ferritin during a competitive running and swimming season. Int J Sports Med 18: 233-237.

22) Auersperper I, Škof B, Leskošek B, Knap B, Jerin A, Lainscak M. 2013. Exercise-induced changes in iron status and hepcidin response in female runners. PLoS One $\mathbf{8}$ : e58090.

23) Ishibashi A, Maeda N, Sumi D, Goto K. 2017. Elevated serum hepcidin levels during an intensified training period in well-trained female long-distance runners. Nutrients 9: 277-285.

24) Nikolaidis PT, Veniamakis E, Rosemann T, Knechtle B. 2018. Nutrition in ultra-endurance: State of the art. Nutrients 10: 1995-2009.

25) Imamura H, Iide K, Yoshimura Y, Kumagai K, Oshikata 
R, Miyahara K, Oda K, Miyamoto N, Nakazawa A. 2013. Nutrient intake, serum lipids and iron status of colligiate rugby players. J Int Soc Sports Nutr 10: 9-17.

26) Ulrich G, Bärtsch P, Friedmann-Bette B. 2011. Total haemoglobin mass and red blood cell profile in endurance-trained and non-endurance-trained adolescent athletes. Eur J Appl Physiol 111: 2855-2864.

27) Malczewska J, Stupnicki R, Blach W, Turek-Lepa E. 2004. The effects of physical exercise on the concentrations of ferritin and transferrin receptor in plasma of male judoists. Int J Sports Med 25: 516-521.

28) Woods A, Garvican-Lewis LA, Saunders PU, Lovell G, Hughes D, Fazakerley R, Anderson B, Gore CJ, Thompson KG. 2014. Four weeks of IV iron supplementation reduces perceived fatigue and mood disturbance in distance runners. PLoS One 9: e108042.

29) Reinke S, Taylor WR, Duda GN, von Haehling S, Reinke P, Volk HD, Anker SD, Doehner W. 2012. Absolute and functional iron deficiency in professional athletes during training and recovery. Int J Cardiol 156: 186-191.

30) Ostojic SM, Ahmetovic Z. 2008. Weekly training volume and hematological status in female top-level athletes of different sports. J Sports Med Phys Fitness 48: 398-403.

31) Mielgo-Ayuso J, Zourdos MC, Calleja-González J, Córdova A, Femandez-Lázaro D, Caballero-García A. 2018. Eleven weeks of iron supplementation does not maintain iron status for an entire competitive season in elite female volleyball players: A follow-up study. Nutrients 10: $1526-1537$.

32) Peeling P, Sim M, Badenhorst CE, Dawson B, Govus AD, Abbiss CR, Swinkels DW, Trinder D. 2014. Iron status and the acute post-exercise hepcidin response in athletes. PLoS One 9: e93002.

33) Voss SC, Varamenti E, Elizain Elgingo M, Bourdon PC. 2014. New parameters and reference values for monitoring iron status in Middle Eastern adolescent male athletes. J Sports Med Phys Fitness 54: 179-185.

34) Govus AD, Garvican-Lewis LA, Abbiss CR, Peeling P, Gore CJ. 2015. Pre-altitude serum ferritin levels and daily oral iron supplement dose mediate iron parameter and hemoglobin mass responses to altitude exposure. PLoS One 10: e0135120.

35) Burden RJ, Pollock N, Whyte GP, Richards T, Moore B, Busbridge M, Srai SK, Otto J, Pedlar CR. 2015. Effect of intravenous iron on aerobic capacity and iron metabolism in elite athletes. Med Sci Sports Exerc 47: 13991407.

36) Walker AJ, McFadden BA, Sanders DJ, Rabideau MM, Hofacker ML, Arent SM. 2019. Biomarker response to a competitive season in division I female soccer players. $J$ Strength Cond Res 33: 2622-2628.

37) Uenishi K, Ishida H, Nakamura K. 2007. Development of a simple food frequency questionnaire to estimate intakes of calcium and other nutrients for the prevention and management of osteoporosis. J Nutr Sci Vitaminol 54: 25-29.

38) Tsugawa N, Uenishi K, Ishida H, Minekami T, Doi A, Koike S, Takase T, Kamao M, Mimura Y, Okano T. 2012. A novel method based on curvature analysis for estimating the dietary vitamin $\mathrm{K}$ requirement in adolescents. Clin Nutr 31: 255-280.

39) Beard JL, Murray-Kolb LE, Rosales FJ, Solomons NW, Angelilli ML. 2006. Interpretation of serum ferritin concentrations as indicators of total-body iron stores in survey populations: The role of biomarkers for the acute phase response. Am J Clin Nutr 84: 1498-1505.

40) Ostrowski K, Rohde T, Asp S, Schjerling P, Pedersen BK. 1999. Pro- and anti-inflammatory cytokine balance in strenuous exercise in humans. J Physiol 515: 287-291.

41) Podgórski T, Kryściak J, Konarski J Domaszewska K, Durkalec-Michalski K, Strzelczyk R, Pawlak M. 2015. Iron metabolism in field hockey players during an annual training cycle. J Hum Kinet 47: 107-114. 